\title{
HYPEROXALURIA IN CHRONIC RENAL DISEASE ASSOCIATED WITH SPINAL CORD INJURY
}

\author{
By N. D. Vaziri, M.D., F.A.C.P., B. NikakhtaR, M.D., and S. Gordon, M.D. \\ Division of Nephrology, University of California, Irvine, $C A$ and Spinal Cord Injury $\mathcal{F}$ \\ Nephrology Sections, Long Beach VA Medical Center, Long Beach, CA, U.S.A.
}

Abstract: Eleven patients who had advanced renal failure associated with spinal cord injury were studied, and the majority exhibited hyperoxaluria, although none showed hypercalciuria. Urinary citrate was markedly reduced in all of the patients.

Key words: Hyperoxaluria; Spinal cord injury; Chronic renal failure.

\section{Introduction}

RENAL failure is one of the major complications of long-standing spinal cord injury (SCI) and the main cause of death in this setting (Price, I 966). Intractable bladder and renal parenchymal infections, and impaired urinary drainage due to the associated neuropathic bladder dysfunction, play the major role in the genesis of chronic renal failure in patients with SCI. Development and progression of renal failure is often accelerated by urolithiasis, a frequent complication of long-standing SCI (Damanski, I963). While the most abundant crystaloid content of the stones is magnesium ammonium phosphate, calcium oxalate is also found with considerable frequency. The role of urinary tract infection with urease-producing organisms in the genesis of magnesium ammonium phosphate stones is well understood. However, the underlying mechanism responsible for incorporation of calcium oxalate is not entirely clear. While hypercalciuria is commonly observed early in the course of SCI (up to several months-Burr, I97I), it may not persist in the face of longstanding injury. The study was undertaken to determine urinary excretion of oxalate and calcium in a group of patients with long-standing spinal cord injury and varied degrees of renal failure.

\section{Patients and Methods}

Eleven men with paraplegia due to spinal cord injury were studied. Their ages ranged between 52 and 71 years (mean $=56 \cdot 5)$. The spinal cord injury had occurred 4 to 37 years (mean 2.5 years) prior to the time of the study. The aetiology of spinal cord injury included compression-fracture of the spine, gunshot injury and spinal cord tumours.

A dietary review revealed the diet to contain approximately: carbohydrate $300 \mathrm{~g}$; protein I00 g; fat I Io g; calcium 500-I $500 \mathrm{mg}$; phosphorus 700-I $440 \mathrm{mg}$; oxalate I00-300 $\mathrm{mg}$; and sodium $2 \cdot 5-4.5 \mathrm{~g}$ per day. All patients received multivitamins. In addition, those with end-stage renal failure received pyridoxin, aluminium car-

All correspondence should be addressed to: N. D. Vaziri, M.D., Division of Nephrology, Department of Medicine, Med. Sci. I, Room C-35 I, University of California, Irvine, California, 92717. 
TABLE I

Clinical Data

\begin{tabular}{cclcc}
\hline Patient & $\begin{array}{c}\text { Age in } \\
\text { years }\end{array}$ & $\begin{array}{c}\text { Level } \\
\text { of } \\
\text { injury }\end{array}$ & $\begin{array}{c}\text { Duration of } \\
\text { SCI in } \\
\text { years }\end{array}$ & $\begin{array}{c}\text { Creatinine clearance } \\
\mathrm{ml} / \mathrm{min}\end{array}$ \\
\hline $\mathrm{I}$ & 49 & $\mathrm{C}_{6}$ & $\mathrm{I} 7$ & $3 \cdot 5$ \\
2 & 62 & $\mathrm{~T}_{5}$ & 36 & $6 \cdot 2$ \\
3 & $7 \mathrm{I}$ & $\mathrm{C}_{5}$ & 3 & $5 \cdot 8$ \\
4 & 68 & $\mathrm{~T}_{12}$ & 36 & $5 \cdot 5$ \\
5 & 53 & $\mathrm{C}_{4}-\mathrm{C}_{5}$ & $2 \mathrm{I}$ & $6 \cdot 5$ \\
6 & 57 & $\mathrm{C}_{5}-\mathrm{C}_{6}$ & 23 & $\mathrm{I} 2 \cdot 0$ \\
7 & 46 & $\mathrm{C}_{5}-\mathrm{C}_{6}$ & 22 & $32 \cdot 0$ \\
8 & 55 & $\mathrm{C}_{5}$ & 36 & $18 \cdot 0$ \\
9 & 32 & $\mathrm{~L}_{4}-\mathrm{L}_{5}$ & $\mathrm{I} 2$ & $2 \mathrm{I} \cdot 0$ \\
$\mathrm{IO}$ & 60 & $\mathrm{~T}_{12}$ & 23 & $\mathrm{I} 6 \cdot 0$ \\
$\mathrm{II}$ & 50 & $\mathrm{C}_{5}-\mathrm{C}_{6}$ & $\mathrm{I} 8$ & $34 \cdot 0$ \\
Mean & 55 & - & $2 \mathrm{I} \cdot \mathrm{I}$ & $\mathrm{I} \cdot 6$ \\
SD & $\pm \mathrm{II}$ & - & $\pm 9 \cdot 4$ & $\pm \mathrm{IO} \cdot 8$ \\
\hline
\end{tabular}

bonate and iron supplement. Indwelling catheters provided the means for urinary drainage in all patients. Fasting, free-flowing venous blood samples were obtained by venepuncture. Plasma concentrations of electrolytes, creatinine, calcium, inorganic phosphorus and uric acid were measured using a multichannel autoanalyzer. Twenty-four-hour urine collections were obtained to quantitate urinary excretion of oxalate, calcium, uric acid, phosphorus and citrate. Bottles containing hydrochloric acid were used to collect urine for calcium determination. Similarly, appropriate preservatives were used in collections for oxalate and citrate. Urine collections were completed shortly before the dialysis treatment preceded by the longest interdialytic interval. Fresh urine samples were collected anaerobically under mineral oil and promptly tested for $\mathrm{pH}$ by $\mathrm{pH}$-meter. Urine culture and urinalysis were also obtained using standard laboratory methods. Linear regression and a $t$-test were used in analysis of the data. Urinary oxalate was measured by gas chromatography.

Patients with creatinine clearances below Io $\mathrm{ml} / \mathrm{min}$ were treated with haemodialysis for 4 hours two to three times weekly (patients I-5). Clinical data are displayed in Table I.

\section{Results}

The patients were divided into two groups depending on the degree of renal failure. Group I consisted of five patients with creatinine clearances less than Io $\mathrm{ml} / \mathrm{min}(3.5$ to $6.2 \mathrm{ml} / \mathrm{min})$, requiring regular dialysis. Group II was comprised of the six remaining patients with creatinine clearances ranging from $12-34 \mathrm{ml} / \mathrm{min}$ (mean $=23 \mathrm{ml} / \mathrm{min}$ ) who did not require dialysis treatment.

Leucocyturia (more than five white blood cells per high power field) and bacteriuria were present in all patients. The organisms recovered on urine culture consisted of E. coli (three), pseudomonas aeruginosa (two), proteus rettgeri (two), proteus vulgaris (two), proteus mirabilis (one) and paracolon (one). The urinary tract infection was asymptomatic in all cases.

$$
20 / \mathrm{I}-\mathrm{D}^{\star}
$$




\section{TABLE II}

Daily urinary excretion of oxalate, calcium, phosphorus, citrate and sodium

\begin{tabular}{|c|c|c|c|c|c|c|}
\hline Patient & $\begin{array}{l}\text { Urine } \\
\text { output } \\
\text { ml/day }\end{array}$ & $\begin{array}{l}\text { Urinary } \\
\text { oxalate } \\
\text { mg/day }\end{array}$ & $\begin{array}{l}\text { Urinary } \\
\text { calcium } \\
\text { mg/day }\end{array}$ & $\begin{array}{c}\text { Urinary } \\
\text { phosphorus } \\
\text { mg/day }\end{array}$ & $\begin{array}{l}\text { Urinary } \\
\text { citrate } \\
\text { mg/day }\end{array}$ & $\begin{array}{l}\text { Urinary } \\
\text { sodium } \\
\text { mg/day }\end{array}$ \\
\hline I & 210 & I $2 \mathrm{I}$ & - & - & - & - \\
\hline 2 & I925 & I 87.9 & 120 & I5 & 52 & 150 \\
\hline 3 & I330 & I 22 & 32 & 49 & 68 & 86 \\
\hline 4 & I I 50 & 68 & 84 & 60 & I 5 I & 342 \\
\hline 5 & 1650 & 714 & $7 \mathrm{I}$ & 45 & 46 & 93.5 \\
\hline 6 & I980 & I4 & 32 & 49 & 68 & 86 \\
\hline 7 & 5500 & 73 & - & - & - & - \\
\hline 8 & 2700 & $2 \mathrm{I}$ & 68 & 32 & 32 & 329 \\
\hline 9 & 3250 & I4 I & 84 & 220 & 47 & 98 \\
\hline IO & 2100 & 82 & I 15.5 & 510 & I55 & I3 I \\
\hline I I & 4590 & 72 & I96 & 94 & 50 & 97 \\
\hline Mean & 2398 & I 47 & 89 & I 19 & 74 & I 57 \\
\hline$\pm \mathrm{SD}$ & I 542 & 195 & 50 & I 58 & 46 & I03 \\
\hline
\end{tabular}

The figures for the relevant plasma values were as follows: $\mathrm{Na}=136 \pm 4$; $\mathrm{K}=4.9 \pm 0.7 ; \mathrm{Cl}=\mathrm{IOI} \pm 5 ; \mathrm{HCO}_{3}^{-}=20 \pm 3.5 \mathrm{mEq} / \mathrm{l} ; \mathrm{Ca}=8.6 \pm 0.5 ;$ phosphorus $=4 \cdot \mathrm{I} \pm \mathrm{I} \cdot 0 ;$ uric acid $=7 \cdot 2 \pm \mathrm{I} \cdot 8$; and creatinine $=4 \cdot 4 \pm \mathrm{I} \cdot \mathrm{I} \mathrm{mg} / \mathrm{dl}$.

Urine $\mathrm{pH}$ measured by $\mathrm{pH}$-meter ranged from $7 \cdot 2$ to $9 \cdot 5$ units. Urine output ranged between 210 to I425, averaging 8I 7 in Group I and I650 to 5500, averaging $3110 \mathrm{ml}$ per 24 hours in Group II. The urinary excretion of oxalate was $147 \pm 195$ $\mathrm{mg}$, ranging from $\mathrm{I} 4$ to $7 \mathrm{I} 4 \mathrm{mg}$ per day. The normal limits established in our laboratory for 24-hour urinary oxalate excretion are 10-40 mg. Urinary oxalate excretion markedly exceeded the normal values in all but two patients. No correlation was found between creatinine clearance and urinary oxalate excretion and there was no significant difference in urinary oxalate excretion between the two groups.

Urinary calcium excretion was $89 \pm 50 \mathrm{mg}$ per day with no patient exhibiting values exceeding $200 \mathrm{mg} / 24$ hours. A significant correlation $(\mathrm{r}=0.67, \mathrm{p}<0.05)$ was found between creatinine clearance and urinary calcium excretion. Urinary phosphorus excretion was I02 $\pm 49 \mathrm{mg}$ per day. Twenty-four-hour urinary citrate was $73 \pm 46 \mathrm{mg}$, with the values below I $40 \mathrm{mg} /$ day in all but two patients. Normal values for urinary citrate excretion established in our laboratory range between 140 and $940 \mathrm{mg}$ per 24 hours. Three of our patients had nephrolithiasis at the time of evaluation. The relevant urinary data are displayed in Table II.

\section{Discussion}

With advanced renal failure, despite a marked reduction of proximal tubular reabsorption and increased fractional excretion of oxalate, plasma oxalate level rises and its urinary excretion falls (Krouri et al., 1980). Paradoxically, however, nine of our I I patients with long-standing spinal cord injury and moderate to severe renal failure exhibited marked hyperoxaluria. The pathogenesis of the hyperoxaluria is 
not clear. Increased endogenous production or enhanced intestinal absorption of oxalate may be responsible for this phenomenon. Primary hyperoxaluria is not a likely cause here due to the rarity of this condition in the general population and lack of prior history in our patients and their relatives. Pyridoxin and thiamin deficiencies can theoretically increase oxalate production by limiting transamination of glyoxalate to glycin, thereby favouring the formation of oxalate (Hodgkinson \& Wilkinson, 1974). This is not likely since the patients were receiving multivitamins and pyridoxin supplements. Moreover, these deficiencies have not been associated with significant hyperoxaluria in man (Coe \& Favis, I980). Excessive doses of ascorbic acid ( $4 \mathrm{~g}$ per day) have been shown to increase oxalate production and excretion in some patients (Hagler \& Herman, 1973). No such history existed in our patients.

Increased oxalate absorption from the gastrointestinal tract may be the main pathogenic mechanism. Since normally only a small fraction (2-4.5 per cent) of dietary oxalate is absorbed (Zaremski \& Hodgkinson, I962; Dobbins \& Binder, I977), increased dietary oxalate is not likely to be responsible for this phenomenon. Furthermore, based on an extensive dietary review in our patients the oxalate intake was not excessive. Malabsorption syndromes with steatorrhoea often lead to increased oxalate absorption and hyperoxaluria. This is due to competition by the unabsorbed fatty acids and bile salts with oxalic acid in the lumen of the gastrointestinal tract for combining with calcium, leaving oxalate in a more absorbable form (Saunders et al., 1975). Although frank malabsorption and steatorrhoea were not observed in our cases, subtle abnormalities of the bowels, pancreas and biliary system associated with amyloidosis, bacterial overgrowth or other conditions may have existed. It has been shown that the colon plays a major role in oxalate absorption in man and monkey (Chadwick et al., I975; Fairclough et al., I977). Disturbance of the anal sphincter as well as colonic motility usually lead to faecal impaction and severe constipation in SCI patients. Prolonged exposure to luminal contents combined with possible bowel pathology may have increased colonic absorption of oxalate in our patients.

Unfortunately, plasma oxalate levels were not measured in our patients. Markedly elevated levels due to reduced urinary excretion, however, have been previously shown in patients with advanced renal failure of other aetiologies (Krouri et al., 1980). Precipitation of calcium oxalate in various tissues can occur in this condition. As mentioned earlier, due to the changes of colonic function, hyperabsorption of oxalate may co-exist with its reduced renal clearance in patients with SCI and advanced renal failure. If this hypothesis is true, plasma and tissue oxalate levels will be higher in these patients as compared to those with chronic renal failure without SCI. If so, oral calcium carbonate, dietary oxalate restriction and reduced dietary content of the long-chain fatty acids may be indicated to reduce gastro-intestinal absorption of oxalate in this setting. Further investigations are required to elucidate the mechanism and treatment of hyperoxaluria in this condition.

Hypercalciuria is commonly found during the early phase of spinal cord injury (Barr, I97I). This has been attributed to the enhanced bone resorption associated with immobilisation. With continued immobilisation the initially accelerated bone resorption and the resultant hypercalciuria may subside. None of our patients with long-standing spinal cord injury and mild to severe renal failure exhibited hypercalciuria. Moreover, urinary calcium excretion in our patients directly correlated with the creatinine clearance $(\mathrm{r}=0.67, \mathrm{p}<0.05)$. This is consistent with the expected alteration of urinary calcium in chronic renal failure. The reduction 
of urinary calcium excretion in chronic renal failure is the consequence of two major processes: (a) reduced filtered load of calcium due to its reduced plasma concentration and decreased glomerular filtration rate and $(b)$ enhanced tubular reabsorption of calcium due to the associated secondary hyperparathyroidism. Changes of urinary calcium excretion in this subgroup of patients with chronic renal disease is thus similar to that observed in chronic renal diseases of other aetiologies.

Urinary citrate is a potent inhibitor of calcium stone formation and its reduction is believed to contribute to the stone-forming diathesis in distal renal tubular acidosis (Dedmon \& Wrong, I 962; Morrissey et al., I 963). Since SCI patients are at high risk for urolithiasis we measured urinary citrate in our patients and found it to be markedly reduced. The mechanism of reduced urinary citrate in our patients is not entirely clear. Systemic acidosis, particularly distal renal tubular acidosis, is known to reduce urinary citrate excretion (Crawford et al., I 959; Dedmon \& Wrong I 962; Morrissey et al., I 963) Although urine $\mathrm{pH}$ was markedly elevated in our patients it was thought to be primarily due to the urinary tract infection found in all cases. A mild renal tubular acidification defect, however, may have been present in some of our patients. Such a tubular dysfunction would not be surprising in view of the tubulo-interstitial nature of the underlying renal disease (chronic obstructive pyelonephritis) in these patients. In addition, the reduction of urinary citrate excretion may be due in part to the marked reduction of renal mass in our patients. Reduced urinary citrate, irrespective of its aetiology, may contribute to the prevalence of urolithiasis in this population.

\section{SUMMARY}

Urinary excretion of oxalate, calcium and citrate were determined in II patients with chronic renal failure associated with long-standing spinal cord injury. Nine of the tested patients exhibited marked hyperoxaluria. The mechanism of the hyperoxaluria is not clear, although colonic hyperabsorption of oxalate may have been responsible. None of the patients exhibited hypercalciuria and all but two had markedly reduced urine citrate, which is a known inhibitor of stone formation. Increased urinary oxalate and reduced urinary citrate may therefore contribute to the stone-forming diathesis in this setting.

Acknowledgment: The authors would like to thank Chris Byrnes for statistical analysis of the data and Sue Burns for preparation of the manuscript.

\section{RÉSUMÉ}

Nous avons déterminé l'excrétion urinaire d'oxalate, de calcium et de citrate dans un groupe de onze patients souffrant de défaillance rénale chronique associée à une blessure de longue durée de la colonne vertébrale. Neuf des patients examinés manifestaient une hyperoxalurie considérable. Le mécanisme par lequel l'hyperoxalurie s'était établie n'est pas devenu évident, bien qu'il soit probable qu'une hyperabsorption d'oxalate par le colon en est responsable. Aucun des patients ne manifestait une hypercalciurie et tous sauf deux avaient un niveau considérablement réduit d'oxalate urinaire, condition que est connue comme inhibitive de la formation de pierres. Il est possible dans ce contexte que le niveau d'oxalate urinaire augmenté et celue de citrate urinaire diminué contribuent à la formation diathétique de pierres rénales.

\section{ZUSAMMENFASSUNG}

Wir haben die Urinausscheidung von Oxalat, Kalzium und Zitrat bei elf Patienten gemessen, bei denen chronisches Nierenversagen verbunden ist mit einer bereits lang 
andauernden Wirbelsäulenverletzung. Neun der untersuchten Patienten wiesen verstärkte Hyperoxalurie auf. Der Mechanismus der beobachteten Huperoxalurie ist nicht klar; möglicherweise handelt es sich um Kolonhyperabsorption von Oxalat. Keiner der Patienten zeigte Hypercalciurie und alle bis auf zwei wiesen stark reduzierte Urinzitratwerte auf, was bekanntlicherweise der Steinbildung entgegenwirkt. Vermehrte Oxalatwerte und reduzierte Zitratwerte im Urin tragen möglicherweise in diesem Zusammenhang zur diathetischen Steinbildung bei.

\section{REFERENCES}

BURR, R. C. (197I). Urinary calcium, magnesium, crystals and stones in paraplegia. Paraplegia, I0, 56-63.

Chadwick, V. S., Elias, E., Bell, G. D. \& Dowling, R. H. (1975). The role of bile acids in the increased intestinal absorption of oxalate after ileal resection. In S. MATERN, J. HACKENSCHMIDT, P. BACH \& W. GeroK (eds.), Advances in Bile Research, Vol. III, Bile Acid Meeting, pp. 435-438. FK Schattauer Verlag, Stuttgart.

CoE, F. \& FAvis, M. (I980). Disorders of stone formation. In B. BRENNER and F. ReCTOR (eds.), The Kidney, 2nd edition, pp. 1991-1992.

Crawford, M. A., Milne, M. D. \& SChribner, B. H. (1959). The effect of changes in acid-base balance on urinary citrate in rat. F. Physiol., 149, 413-423.

Damanski, M. (1963). Stone disease in paraplegia. Paraplegia, I, I49-156.

DEDMON, R. E. \& WRONG, O. (1962). The excretion of organic anion and renal tubular acidosis with particular reference to citrate. Clin. Sci., 22, I9-32.

DobBINS, J. W. \& BINDER, H. J. (I977). Importance of colon in enteric hyperoxaluria. N. Engl. F. Med., 296, 298-301.

Fairclough, P. D., Feest, T. G., Chadwick, V. S. \& Clark, M. L. (I977). Effect of sodium chenodeoxycholate on oxalate absorption from the excluded human colona mechanism for 'enteric' hyperoxaluria. Gut, 18, 240-244.

Hagler, L. \& Herman, R. H. (1978). Oxalate metabolism. Am. F. Clin. Nutr., 26, 758-1242.

Hodgkinson, A. \& Wilkinson, R. (1974). Plasma oxalate concentration and renal excretion of oxalate in man. Clin. Sci. Mol. Med., 46, 6I-73.

Krouri, A., Jacobs, C., Charransol, G. \& J. P. Clavel Group. (I980). Plasma and urinary oxalic acid in normal subjects, in patients with chronic renal failure and in patients treated by maintenance haemodialysis. Kidney International, 18, 799.

Morrissey, J. F., OchoA, M., Lotspeich, W. D. \& Waterhouse, C. (I963). Citrate excretion in renal tubular acidosis. Ann. Intern. Med., 58, 159-I66.

PRICE, M. (I966). Renal function in patients with spinal cord injuries. Proc. Ann. Spinal Cord Inj. Conf., 15, 15-20.

SAUnders, D. R., Sillery, J. \& MCDonald, G. B. (1975). Regional differences in oxalate absorption by rat intestine; evidence for excessive absorption by the colon in steatorrhea. Gut, 16, 543-554.

ZAREMSKI, P. M. \& Hodgrinson, A. (I962). The oxalic acid content of the English diets. Brit. F. Nutr., 16, 627-634. 